\title{
What drives green development in China: public pressure or the willingness of local government?
}

\author{
Zhengda $\mathrm{Li}^{1} \cdot$ Yihan $\mathrm{Hou}^{1} \cdot$ Junli Cao ${ }^{1} \cdot$ Yanping Ding ${ }^{1} \cdot$ Xiaoling Yuan ${ }^{2}$ \\ Received: 14 May 2021 / Accepted: 16 August 2021 / Published online: 22 August 2021 \\ (C) The Author(s), under exclusive licence to Springer-Verlag GmbH Germany, part of Springer Nature 2021
}

\begin{abstract}
With China already committing to peak carbon dioxide emissions before 2030 and achieving carbon neutrality before 2060, green development is urgent. It is necessary to clarify the driving mechanism of green development to design the path of green development scientifically. From the internal perspective of the green development system, this paper divides the green development power into external power and internal power. The external power is the political pressure formed by the public's green demands. The internal power is the endogenous power of green development transformed by the political promotion willingness of local government leaders. The research shows that (1) the green demands from the public and the accompanying political pressure can form the driving force of green development. (2) The political promotion intention has not been transformed into the endogenous driving force to promote green development in the research period. (3) The external driving force of public appeal is closely related to economic development, income and consumption levels, and education. This paper enriches the research literatures on the driving mechanism of green development and provides theoretical and practical exploration for the driving path of green development.
\end{abstract}

Keywords Green development $\cdot$ Public pressures $\cdot$ Local government willingness $\cdot$ Total factor productivity $\cdot$ MEBM-Luenberger

\section{Introduction}

The Chinese government has already deemed "Green" as one of the "five major" concepts for overcoming obstacles to development, enhancing the developmental momentum and

Responsible Editor: Ilhan Ozturk

Zhengda Li

lizhengda@xauat.edu.cn

Xiaoling Yuan

xiaoling@xjut.edu.cn

Yihan Hou

houyh@xauat.edu.cn

Junli Cao

caojunli@xauat.edu.cn

Yanping Ding

dingyp@xauat.edu.cn

1 School of Management, Xi'an University of Architecture and Technology, 710055 Xi'an, Shaanxi, People's Republic of China

2 School of Economics and Finance, Xi'an Jiaotong University, 710061 Xi'an, Shaanxi, People's Republic of China strengthening the advantages in development. The government and the public are indispensable elements in green development. In the early stage, scholars thought that environmental pollution caused "market failure" due to externality and inefficiency (Klein 2019). In the later stage, scholars thought that the government caused "government failure" in environmental governance because of the management system, decision efficiency and rent-seeking (Backhouse and Medema 2012; Keech and Munger 2015; Kosar and Winston 2008). Public governance theory gives full play to the unique and important role of the third sector; it holds that the public is an effective way to solve the "market failure" and "government failure" of environmental governance (Fike and Gwartney 2015). They believe that, based on the theory of democracy, public participation has the advantages of legitimacy, justice, protection of freedom and social interests, improving the effectiveness of decision-making and implementation. The public can judge the government's public services by "voting with their hands" and "voting with their feet" and use the signal effect to form the external driving force for green development. On the other hand, local governments have the right to allocate resources for environmental governance in China's current management system. They are the 
planners of green development strategy, the suppliers of the green development system and the regulators of green production and life. Their unique position makes them have the natural authority of economic and social development. However, whether the local government has the endogenous driving force of green development has multiple nonlinear and uncertain characteristics in the realistic of "political tournament" about local government officials(Chen et al. 2017). It provides research motivation for this paper. Does China's green development come from the public or local government? Who is the real driving force for green development? Answering these questions is of great theoretical and practical significance for scientifically designing the guiding mechanism of green development to achieve the goal of "promoting the comprehensive green transformation of economic and social development" during the 14th Five-Year Plan period.

According to present literatures, the factors affecting green development are divided into macro and micro factors. Viewpoints on the macro factors can be classified into three categories: first, it is considered that a country's fiscal, tax and environmental governance policies are of great significance for promoting green development (Fabrizi et al. 2018; Galinato and Chouinard 2018; Gao et al. 2018; Onuoha et al. 2018). Secondly, the effect of industrial resource endowment should not be overlooked, and the geographical conditions, natural resource endowment, environmental softening, etc., have a marked effect on green development (MacDonald and Eyre 2018; Mekala and Hatton MacDonald 2018). Thirdly, the green values and green consumption consciousness in the society have a direct and lasting impact on green development (Mittal and Dhar 2016). The viewpoints on the micro factors can also be divided into three categories: the first holds that green development can be driven by developing green products and implementing green marketing (Sarmiento and El Hanandeh 2018; Simão and Lisboa 2017; Ye and Lin 2020); the second believes that green development can be boosted through the introduction of green production technologies, resource recycling and green production (Noble 2021; Singh et al. 2018); the third considers that enterprises should establish value chains and supply chains for green products to facilitate green development (de Medeiros et al. 2018; Wang et al. 2019).

The current literatures provide theoretical and practical evidence to understand the driving factors of green development. However, most of literatures discuss driving factors from the external perspective of the green development system, and there are few literatures from the internal perspective. Consequently, it is impossible to reveal the internal context of green development, which weakens the roles of policy tools and planning measures on green development. Accordingly, we attempt to expand the literatures as follows: (1) The green development mechanism was explored from the internal perspective, trying to provide a new perspective for green development to open the "black box of dynamics" of green development. Green development was divided into external dynamics based on public demands with the environment and internal dynamics based on the development willingness of the government. (2) Green development was set in a strong sustainable development framework, making attempts to develop new research methods for green development. Strongly sustainable development is a pattern of economic development under the non-degenerate constraint of main natural capitals and formally established by the United Nations as a new paradigm for green development in 2012. Based on the requirements of non-decreasing development of environmental welfare, the ecological environment was divided into ecological damage and ecological construction, and it was introduced into linear programming function with economic output to discover the restraining effect of strongly sustainable development. (3) The level of green development was regarded as the integration of green development efficiency and its contribution, striving to measure the level of green development from the two dimensions of process and effect. They are calculated by using MEBM and MEBM-Luenberger algorithms, which specify the constraint conditions of variable parameters, avoid potential logic errors that will occur in projection values and overcome the phenomena of "paradox in the correlation index theory" that appears between the projection values of input indices due to the linear negative correlation.

\section{Method}

An econometric model was created to test the external and internal dynamics of green development. The model is as follows:

$$
\begin{aligned}
\text { greenindex }=C & +\beta_{1} \operatorname{exter}_{i, t}+\beta_{2} \operatorname{inner}_{i, t}+\beta_{3} \operatorname{inp}_{i, t}+\beta_{4} \operatorname{fip}_{i, t} \\
& +\beta_{5} \operatorname{urp}_{i, t}+\beta_{6} \operatorname{edup}_{i, t}+\beta_{7} \operatorname{eip}_{i, t}+\beta_{8} \operatorname{road}_{i, t} \\
& +\beta_{9} \operatorname{popu}_{i, t}+\delta .
\end{aligned}
$$

\section{Dependent variables}

greenindex represents the level of green development. China faces dual pressures from economic development and environmental protection. There is no choice but to improve its total factor productivity (TFP). TFP is the ratio of outputs and inputs, which includes the direct influences from technology, employee's skill, production process, managerial improvements, etc. The traditional TFP only considered the input constraints of labor, capital and other production factors but did not consider the constraints of resources and environment, distorting the evaluation of social welfare changes and economic performance (Hailu and Veeman 2020). Chung et al. (1997) creatively introduced the directional distance function 
(DDF) and Malmquist-Luenberger productivity index (ML index). In this model, the TFP was measured with undesirable outputs and pollution outputs into account, so it was green total factor productivity (GTFP) (Janaiah et al. 2006). TFP and GTFP had double meanings of quality and quantity. From the perspective of quantity, they explain the value produced by various input factors and their combinations in a certain period (Nin-Pratt et al. 2010). On the other hand, the growth of TFP reflects the transformation effect and development quality by analyzing its contribution to economic growth (Liu et al. 2016). Thus, GTFP is a useful metric for measuring green development (Tao et al. 2017; Feng et al. 2018; Grillitsch and Hansen 2019). In this study, the green development level is measured from the two dimensions of quality and quantity; greenindexis regarded as the product of GTFP and its contribution (CGTFP), which is different from current literatures.

\section{GTFP}

The efficiency calculation methods can be divided into radial and non-radial methods. According to the radial calculation method, the input or output factors need to be changed in the same proportion when evaluating the efficiency, which is inconsistent with actual conditions; moreover, a choice needs to be made on whether it is based on input or output orientation to calculate the efficiency values, and the two aspects of input and output cannot be considered simultaneously in this method, which will distort efficiency values. In addition, when the input is excessive or the output is insufficient, which means the slack variable of input or output exists, the radial evaluation method will overestimate the efficiency and mislead the evaluation of the decision-making unit on efficiency. The nonradial calculation method contains non-radial slack variables and thus avoids assuming that factor inputs are reduced or expanded in the same proportion. However, such optimization ignores the original proportion of information on the projection value of the efficient frontier. While the non-radial calculation method adopts a linear planning approach. When the slack variable is chosen to be positive and zero, the difference between its calculation results is very significant. To make up for the weaknesses of the radial and non-radial calculation methods for total factor productivity, Tone and Tsutsui (2010) proposed a new composite model of Epsilon-based measure (EBM), which includes non-radial and radial features in a united framework. He defined the EBM composite distance model as follows:

$$
\begin{gathered}
\gamma^{*}=\min _{\theta, \lambda, s^{-}} \theta-\varepsilon_{x} \sum_{i=1}^{m} \frac{w_{i}^{-} s_{i}^{-}}{x_{i 0}} \quad \text { s.t. } \theta x_{i 0}-X \lambda+s^{-} \\
=0 \quad \mathrm{Y} \lambda \geq \mathrm{y}_{0} \lambda \geq 0, \quad \mathrm{~s}^{-} \geq 0
\end{gathered}
$$

where, $\gamma^{*}$ represents the optimal efficiency value, $\theta$ represents the efficiency value in the calculation based on the radial model, $s_{i}^{-}$represents the slack variable of input for the $i^{\text {th }}$ factor input and $w_{i}^{-}$represents the weight of the $i^{\text {th }}$ factor input. $w^{-}=\left(w_{1}^{-} \cdots w_{m}^{-}\right)$and $\sum_{i=1}^{m} w_{i}^{-}=1 \quad\left(w_{i}^{-} \geq 0, \forall i\right)$ is met; $\varepsilon_{x}$ is an important parameter, which contains the change proportion $\theta$ and non-radial slack variables, and $w_{i}^{-}$and $\varepsilon_{x}$ need to be pre-defined. From the term $\frac{w_{i}^{-} s_{i}^{-}}{x_{i 0}}$ in the formula (2), it shows that the unit is unchanged for $\frac{s_{i}^{-}}{x_{i 0}}$. Therefore, $w_{i}^{-}$should be deemed as a numeric value with a constant unit and reflects the relative importance of the input resource $i$.

Proposition 1: $\gamma^{*}$ meets the condition: $0 \leq \gamma^{*} \leq 1 ; \gamma^{*}$ is an independent unit and a value with a fixed unit.

Proposition 2: if $\varepsilon_{x}=0$, Formula (3) will become an inputoriented CCR model.

Proposition 3: if $\varepsilon_{x}=1$ and $\theta=1$, formula (3) will become an input-oriented SBM model. The EBM model is a composite model and an exception that includes a radial CCR model and a non-radial SBM model, but it is essentially a non-radial model.

Proposition 4: $\varepsilon_{x}$ has a limited optimal value, $\varepsilon_{x} \in[0,1]$.

Proposition 5: if $\varepsilon_{x}>1$, formula (2) is an unbounded solution.

Proposition 6: $\gamma^{*}$ in $\varepsilon_{x}$ is a non-growth value, $D M U_{0}$ is defined as an input efficiency value of the EBM model when $\gamma^{*}=1$; the projection of $\operatorname{DMU}\left(x_{0}^{*}, y_{0}^{*}\right)$ is defined as follows:

$$
\begin{gathered}
x_{0}^{*}=X \lambda^{*}=\theta^{*} x_{0}-s^{-*} \\
y_{0}^{*}=Y \lambda^{*} .
\end{gathered}
$$

Proposition 7: the projection of $\operatorname{DMU}\left(x_{0}^{*}, y_{0}^{*}\right)$ is the input efficiency of the EBM model. Formula (3) can be written as follows:

$$
\begin{aligned}
\gamma^{*} & =\min _{\theta, \lambda, s^{-}}\left(1-\varepsilon_{x}\right) \theta+\varepsilon_{x} \sum_{i=1}^{m} \frac{w_{i}^{-} s_{i}^{-}}{x_{i 0}} \quad \text { s.t. } x-X \lambda=0 x \\
& =\theta x_{0}-s^{-} \quad \mathrm{Y} \lambda \geq \mathrm{y}_{0} \lambda \geq 0, \quad \mathrm{~s}^{-} \geq 0 .
\end{aligned}
$$

Formula (4) shows that $\gamma^{*}$ can be essentially divided into the radial term $\theta$ and the non-radial term $\sum_{i=1}^{m} \frac{w_{i}^{-} s_{i}^{-}}{x_{i 0}} \cdot w_{i}^{-}$and $\varepsilon_{x}$ in the EBM model are key parameters. To determine $w_{i}^{-}$and $\varepsilon_{x}$, Tone and Tsutsui (2010) firstly created a correlation index between different factor inputs in the decision-making unit to replace the Pearson correlation coefficient. The correlation index $S(a, b)$ of the factor inputs $a$ and $b$ in all the decisionmaking units has the following attributes:

Attribute 1 (Identity): $S(a, a)=1$, and its correlation coefficient is 1 . 
Attribute 2 (Symmetry): $S(a, b)=S(b, a)$, and the calculated index is irrelevant with the sequential order of the two indicators.

Attribute 3 (Constant unit): $S(t a, b)=S(a, b) \quad(t>0)$, and the unit of measurement does not affect the results. Attribute 4 (Interval property): $0 \leq S(a, b) \leq 1$, and the calculated data value is between 0 and 1 .

Tone and Tsutsui (2010) proposed to calculate the discrete index pairwise first and then calculate correlation indices using the discrete index.

$S(a, b)=1-2 \mathrm{D}(a, b)(5)$

$D(a, b)$ is the discrete index of the factor inputs $a$ and $b$, representing the dispersion degree of $a, b$. It is defined as follows:

$$
D(a, b)= \begin{cases}\frac{\sum_{j=1}^{n}\left|c_{j}-\bar{c}\right|}{n\left(c_{\max }-c_{\min }\right)} & \left(\text { if } c_{\max }>c_{\min }\right) \\ 0 & \left(\text { if } c_{\max }=c_{\min }\right)\end{cases}
$$

where, $c_{j}=\ln ^{\frac{b_{j}}{-}} a_{j}, \bar{c}=\frac{1}{n} \sum_{j=1}^{n} \ln ^{\frac{b_{j}}{-}} a_{j}, c_{\max }=\max \left(c_{j}\right), c$ $\min =\min \left(c_{j}\right)$. correlation index matrix $S=\left[s_{i j}\right] \in R^{m \times m}(i, j=1, \ldots, m)$, $0 \leq s_{i j} \leq 1 \quad(\forall(i j))$ and obtain the largest eigenvalue $\rho_{x}$ and the largest eigenvector $W_{X}$ of the correlation index matric $S$, and 1 $\leq \rho_{x} \leq m, W_{x} \geq 0$; then,

$\varepsilon_{x}= \begin{cases}\frac{m-\rho_{x}}{m-1} & (\text { if } m>1) \\ 0 & (\text { if } m=1)\end{cases}$

$w^{-}=\frac{W_{x}}{\sum_{i=1}^{m} W_{x i}}$.

Substitute Formula (7) and (8) into Formula (4), and the efficiency value in the EBM model was obtained.

Cheng and Zervopoulos (2014) argued that there were two issues overlooked in the EBM model: One is that the range of the variables $\theta$ and $\varphi$ was not defined. If the input-oriented CRS (Constant returns to scale) model was used for programming solution when $\theta$ lost constraint conditions, $\gamma^{*}$ was likely larger than 1 , and the projection value of the invalid input indicator in the decision-making unit was probably higher than its original value. There would be a wrong conclusion that the target of improvement was "to increase inputs". Similarly, if the output-oriented CRS (Constant returns to
Based on Formula (5) and (6), it is possible to form the

scale) model was used for programming solution when $\varphi$ lost constraint conditions, $\gamma^{*}$ was likely smaller than 1 , and the projection value of the invalid input indicator in the decision-making unit was probably lower than its original value. There would be the wrong conclusion that the target of improvement was "to reduce outputs". The other is that the calculation method for correlation indices was not consistent with his built theory for correlation indices. It was more advisable to adopt the correlation index calculated with the Pearson correlation coefficient to create the parameters of the EBM model. Thus, they proposed an improved EBM model (MEBM):

$$
\begin{aligned}
\gamma^{*} & =\min _{\theta, \lambda, s^{-}} \theta-\varepsilon_{x} \frac{1}{\sum_{i=1}^{m} w_{i}^{-}} \sum_{i=1}^{m} \frac{w_{i}^{-} s_{i}^{-}}{x_{i 0}} \text { s.t. } \theta x_{i 0}-X \lambda-s^{-} \\
& =0 \quad \mathrm{Y} \lambda \geq \mathrm{y}_{0} \lambda \geq 0, \quad \mathrm{~s}^{-} \geq 0, \theta \leq 1 .
\end{aligned}
$$

The following formula is adopted in calculating the correlation index of the two indicators:

$S(a, b)=0.5+0.5 P(a, b)$

where, $P(a, b)$ is the Pearson correlation coefficient of the two indicators.

\section{CGTFP}

We employ Luenberger indices (Chambers 2002) to measure the growth of GTFP (GGTFP), which decompose the GGTFP into the pure efficiency change (LPEC), pure technical progress (LPTP), scale efficiency change (LSEC) and technical scale change (LTPSC). On this basis, CGTFP was calculated through the comparison of GGTGP and economic growth. Compared with the Malmquist productivity index, the Luenberger index overcomes the heterogeneity that potentially occurs between the evaluated unit sets without needing to choose the measurement angle and to carry out changes in the same proportion. The decomposition model, a decomposition method based on different values with an additive structure, can investigate the changes in the total output and provide the foundation for realizing total factor decomposition.

$$
\begin{aligned}
& \text { GGTFP }=\text { LPEC }+ \text { LPTP }+ \text { LSEC }+ \text { LTPSC } \\
& \operatorname{LPEC}_{t}^{t+1}=\overrightarrow{s_{v}^{t}}\left(x^{t}, y^{t} ; g\right)-\overrightarrow{s_{v}^{t+1}}\left(x^{t+1}, y^{t+1} ; g\right)
\end{aligned}
$$

$\operatorname{LPTP}_{t}^{t+1}=\frac{1}{2}\left\{\left[\overrightarrow{s_{v}^{t+1}}\left(x^{t}, y^{t} ; g\right)-\overrightarrow{s_{v}^{t}}\left(x^{t}, y^{t} ; g\right)\right]+\left[\overrightarrow{s_{v}^{t+1}}\left(x^{t+1}, y^{t+1} ; g\right)-\overrightarrow{s_{v}^{t}}\left(x^{t+1}, y^{t+1} ; g\right)\right]\right\}$ 


$$
\begin{aligned}
& \operatorname{LSEC}_{t}^{t+1}=\left[\overrightarrow{s_{c}^{t}}\left(x^{t}, y^{t} ; g\right)-\overrightarrow{s_{v}^{t}}\left(x^{t}, y^{t} ; g\right)\right]-\left[\overrightarrow{s_{c}^{t+1}}\left(x^{t+1}, y^{t+1} ; g\right)-\overrightarrow{s_{v}^{t+1}}\left(x^{t+1}, y^{t+1} ; g\right)\right] \\
& \operatorname{LTPSC}_{t}^{t+1}=\frac{1}{2}\left\{\left[\left(\overrightarrow{s_{c}^{t+1}}\left(x^{t}, y^{t} ; g\right)-\overrightarrow{s_{v}^{t+1}}\left(x^{t}, y^{t} ; g\right)\right)-\left(\overrightarrow{s_{c}^{t}}\left(x^{t}, y^{t} ; g\right)-\overrightarrow{s_{v}^{t}}\left(x^{t}, y^{t} ; g\right)\right)\right]+\right. \\
& \left.\left[\left(\overrightarrow{s_{c}^{t+1}}\left(x^{t+1}, y^{t+1} ; g\right)-\overrightarrow{s_{v}^{t+1}}\left(x^{t+1}, y^{t+1} ; g\right)\right)-\left(\overrightarrow{s_{c}^{t}}\left(x^{t+1}, y^{t+1} ; g\right)-\overrightarrow{s_{v}^{t}}\left(x^{t+1}, y^{t+1} ; g\right)\right)\right]\right\}
\end{aligned}
$$

$\overrightarrow{s_{c}^{t}}\left(x^{t}, y^{t} ; g\right)$ is the MEBM in period $t$ and the technology in period $t$ on the assumption of constant returns to scale (CRS); $\overrightarrow{s_{c}^{t+1}}\left(x^{t}, y^{t} ; g\right)$ is the MEBM in period $t$ and the technology in period $t+1$ on the assumption of constant returns to scale (CRS); $\overrightarrow{s_{c}^{t+1}}\left(x^{t+1}, y^{t+1} ; g\right)$ is the MEBM in period $t+1$ and the technology in period $t+1$ on the assumption of constant returns to scale (CRS). $\overrightarrow{s_{v}^{t}}\left(x^{t}, y^{t} ; g\right)$ is the MEBM in period $t$ and the technology in period $t$ on the assumption of variable returns to scale (VRS); $\overrightarrow{s_{v}^{t+1}}\left(x^{t}, y^{t} ; g\right)$ is the MEBM in period $t$ and the technology in period $t+1$ on the assumption of variable returns to scale (VRS); $\overrightarrow{s_{v}^{t}}\left(x^{t+1}, y^{t+1} ; g\right)$ is the MEBM in period $t+1$ and the technology in period $t$ on the assumption of variable returns to scale (VRS); $\overrightarrow{s_{v}^{t+1}}$ $\left(x^{t+1}, y^{t+1} ; g\right)$ is the MEBM in period $t+1$ and the technology in period $t+1$ on the assumption of variable returns to scale (VRS).

\section{Input indicators}

(1) Capital stock. The most frequently used method is Perpetual Inventory Method to calculate capital stock.

$$
K_{t}=K_{t-1}(1-\delta)+I_{t}(16)
$$

where $K_{t}$ represents the capital stock of the current period, $K_{t}-1$ represents the capital stock of the previous period, $\delta$ represents the economic depreciation rate and $I_{t}$ is the increase in fixed assets in the current year. 1952 was the initial period; the gross domestic fixed capital formation was chosen as $I_{t}$, which was converted to the constant price of 1995 by the investment price index, with the depreciation rate calculated uniformly as per $9.6 \%$. The data stems from the China Statistical Yearbook and the Statistics on Investment in Fixed Assets of China.

(2) Human capital. Human capital was defined as a set of the quantity and quality of labor.

$\mathrm{Hr}=\mathrm{lab} \times \mathrm{edu}$ $\mathrm{edu}=p_{1} \times 15.5+p_{2} \times 12+p_{3} \times 9+p_{4} \times 6$

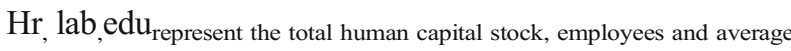
years of schooling in the provinces respectively; $p_{1} p_{2}, p_{3} p_{4 \text { represent the }}$ proportion of the population with an associate degree or higher, proportion of that population with a high school diploma, proportion of the population with a middle school diploma and proportion of the population with a primary school diploma respectively. The data originates from the China Statistical Yearbook and the China Population Statistical Yearbook.

(3) Energy inputs. According to the theory of strong sustainable development, renewable energy should be widely used to realize the non-decreasing development of natural resources. The inputs of energy were divided into clean energy and non-clean energy categories due to the lack of renewable energy data in China. The clean energy is natural gas and electricity (including solar energy, wind power, geothermal energy, nuclear power generation.). Non-clean energy is the total consumed energy except for clean energy. The data stems from the China Statistical Yearbook and the China Energy Statistical Yearbook.

\section{Output indicators}

(1) Good output indicator. The GDP is a good output indicator; it converted into the constant price of 1990. The data originates from the China Statistical Yearbook.

(2) Bad output indicators. Environmental pollutions are a bad output indicator. Based on the theory of strong sustainable development, the non-decreasing development of natural resources requires that the total environmental welfare cannot be reduced only by improving the ability of environmental absorption (self-purification). Environmental absorption (self-purification) refers to the ability of nature to gradually absorb and eliminate pollution under the action of physics, chemistry and biology. Improving environmental absorptive capacity is inseparable from ecological construction, so we examine environmental pollutions from two dimensions of ecological damage and ecological construction. 
Distinct from other researchers who focus only on the damage the industry causes to the eco-environment, the domestic pollutant discharge was included in the measure indicators. The domestic pollutant discharge is reflected by the amount of domestic wastewater discharged and the amount of domestic waste disposed of. As fertilizers and agricultural chemicals were inappropriately used at a large scale, soil pollution in China seemed to be getting worse, causing the soil quality to exhibit a decreasing and deteriorating trend. China accounts for $16 \%$ of the global grain output and $31 \%$ of the global agricultural chemical consumption. The fertilizer consumption per hectare of the arable land in China is four times the global average level. Excessive fertilizers are flushed down to the underground by water, affecting the quality of soils. Fertilizer consumption in China is up to 1.8 million tons and $50 \%$ higher than the global consumption, but the effective utilization rate is less than $30 \%$. Excessive agricultural chemicals not only result in soil pollution but also lead to the occurrence of pesticide residues on agricultural products such as grains, food, fruits and vegetables, which exceed the safety standard and even strengthen the immunity to crop diseases and insect pests. This paper includes fertilizer consumption and agricultural chemical consumption in the evaluation system to reflect agricultural pollution. As the formal official statistics in China do not contain the indicators for carbon dioxide $\left(\mathrm{CO}_{2}\right)$ emissions, in this paper, the energy consumption is used to calculate carbon dioxide emissions according to the method described in the 2006 IPCC Guidelines for National Greenhouse Gas Inventories.

The comprehensive measure system for the ecoenvironment is shown in Table 1.

The deviation maximization method is used as an evaluation approach (Yi et al. 2019). It is an entirely objective weighting method and avoids the subjective impacts from measurers. The environmental construction index and the environmental damage index were calculated, and the composite index of the environment is defined as follows:

$\mathrm{EI}=\mathrm{EP} *(1-\mathrm{EB})$

EIrepresents the composite index of the environment, EP represents the environmental pollution index and EB represents the environmental construction index.

\section{Independent variables}

(1) External dynamics. exteris used to measure the public demands on green development. The main channels for the public to express their demands include public complaints and proposals, proposals from the People's Congress and the Political Consultative Conference, administrative litigation and administrative arbitration on environmental protection and participation in hearings on environmental impact assessment. In this study, the total number of public complaints and proposals $\left(\right.$ exter $\left._{1}\right)$ received by environmental protection agencies in each province and the number of public complaints and proposals per 10,000 persons (exter 2 ) were used to characterize the external dynamics. To keep the data stable, the total number of public complaints and proposals $\left(\right.$ exter $\left._{1}\right)$ is a logarithmic value. The data are derived from the annual data of letters and visits in the China Environmental Yearbook and the China Statistical Yearbook.

(2) Internal dynamics. As an implementer of economic policies and an advocate of regional system supply, local
Table 1 Eco-environment evaluation system

\begin{tabular}{lll}
\hline Level 1 indicator & Level 2 indicator & Unit \\
\hline Environmental construction & Arable land area & Hectare \\
& Urban green space & Hectare \\
& Total volume of water resources & 100 million cubic meters \\
& Forest land area & 10 thousand hectares \\
& Forest area & 10 thousand hectares \\
& Wetland area & thousand hectares \\
& Total amount of industrial wastewater discharged & 10 thousand tons \\
& Amount of domestic wastewater discharged & 10 thousand tons \\
& Industrial waste gas emission & 100 million cubic meters \\
& Industrial sulfur dioxide emission & 10 thousand tons \\
& Amount of industrial solid wastes generated & 10 thousand tons \\
& Total carbon dioxide emission & 100 million tons \\
& Amount of domestic waste disposed & 10 thousand tons \\
& Fertilizer consumption & 10 thousand tons \\
& Agricultural chemical consumption & 10 thousand tons \\
\hline
\end{tabular}


government officials have a wide variety of resources and means at their disposal. Especially, the senior officials in local governments hold a high-ranking position, which has a profound influence on local economic operation. In China's management system, the central government implements strategic programs of development through administering the local officials, and in particular, the selection, appointment, assessment and other incentive systems play a significant role. The top-down management model, coupled with local government officials' idea of realizing personal value through the political position, carried out "promotion tournaments" among local government officials. Regional economic competition is the main form of "promotion tournaments". The local government officials will strategically choose economic development and resource allocation to achieve political promotion. Therefore, the root of the local government's willingness to promote green development is the political promotion willingness of the main leaders, which is the fundamental internal driving force of green development. From the governors' perspective, we observe the motivation of local government officials to promote green development from their political promotion intention:

Internal $=$ time $\times$ promote $\times$ region.

time means the period in office. The longer one holds office, the stronger his willingness to get promoted is, the stronger his motive for winning the political competition by facilitating local development is. promote is the coefficient of promotion. The promotion coefficient was defined as 1.1 for the promotion from the governor to provincial Party Secretary, 1.2 for the appointment as chief in the central department (including government and Party affair departments), 1.5 for the appointment as Member of the Political Bureau of the CPC Central Committee, Vice-Premier of the State Council, a subnational leader in the National People's Congress (NPC) and the Chinese People's Political Consultative Conference (CPPCC); 1.1 for the transfer to Vice-Chairmen of the Special Committees under NPC and CPPCC; 0.9 for transfer to the chairman of the local people's congress and chairman of the local people's political consultative conference and retirement and 0.7 for being under investigation or punished. region is a regional coefficient. 1.1 is for taking office from the central-western provinces to the eastern, and 1 for taking office from the eastern provinces to the western. The uncertainty of the tenure of new officials should be taken into consideration. If a new officer is appointed for or removed from a post in the first half of the year, the provincial governor's tenure will be calculated from this year; if a new officer is appointed for or removed from a post in the second half of the year, the provincial governor's tenure will be counted from next year.
Correspondingly, if a provincial governor leaves his/her post in the first half of the year, the same year will not be counted in the period in office; if he/she leaves his/her post in the second half of the year, the same year will be counted in the period in office. The data above stem from CSMAR.

\section{Control variables}

Industrial structure adjustment is one of the effective measures for achieving green development (Zhu et al. 2019). Fixedasset investments have contributed significantly to energy consumption and green development ( $\mathrm{Hu} 2012$ ). Urbanization is the main thrust of China's economic and social development (Liu et al. 2019). Education is helpful for citizen quality and human capital and improves the level of green development ( $\mathrm{Li}$ et al. 2020). Awan et al. (2021) highlight the importance of investment in environmental management for overcoming environmental challenges. Therefore, the Control variables selected are as follows:

inp represents the contribution of the added value of the second industry in the economic structure, which is used to measure the effect of industrial transformation. At the time of calculation, the added value of the second industry and the GDP of each year are deflated to the constant price of 1990 . fiprepresents the rate of fixed capital formation, that is, the proportion of the amount of fixed capital formation in the GDP of the same year, which is used to represent the economic development mode. urp stands for the level of urbanization and is represented by the proportion of the urban permanent resident population in the total permanent resident population. eduprepresents the proportion of educational appropriations in GDP, which is used to judge the level of education inputs. eip represents the proportion of environmental governance inputs in GDP and is used to test the level of ecological governance. In order to avoid the endogeneity problem, this paper takes the fully exogenous indicators of the road mileageroadand the population size popu as control variables and uses the logarithmic function on the two indicators to ensure smoothness. The data above originate from the China Population Statistics Yearbook and the China Labor Statistics Yearbook, and so on.

\section{Research period and samples}

In this paper, 1996-2018 was chosen as the research period. The ninth Five-Year Plan formulated in 1996 proposed the direction towards realizing the transformation of the economic development mode from extensive to intensive. It is a fundamental transformation with strategic significance and has a profound influence on sustainable development in China. Therefore, 1996 was taken as the starting point of the research period. Given that many data on Tibet were lost, the 30 research samples, except Tibet, were chosen from provinces, autonomous regions and municipalities in mainland China. 
Table 2 Descriptive statistics of the testing of the dynamic mechanism of green development in China

\begin{tabular}{|c|c|c|c|c|c|c|}
\hline Variables & Unit & $\begin{array}{l}\text { Sample } \\
\text { size }\end{array}$ & Mean & $\begin{array}{l}\text { Standard } \\
\text { deviation }\end{array}$ & Min. & Max. \\
\hline $\ln \left(\right.$ exter $\left._{1}\right)$ & piece & 630 & 9.564 & 1.296 & 4.03 & 21.78 \\
\hline exter $_{2}$ & $\begin{array}{l}\text { piece/10 thousand } \\
\text { persons }\end{array}$ & 630 & 6.729 & 6.78 & 0.01 & 43.25 \\
\hline Internal & - & 630 & 5.81 & 2.876 & 1 & 13.2 \\
\hline fip & $\%$ & 630 & 60.723 & 18.661 & 31.8 & 138.07 \\
\hline urp & $\%$ & 630 & 38.425 & 10.488 & 14.04 & 62.6 \\
\hline inp & $\%$ & 630 & 45.292 & 5.225 & 34.8 & 58.4 \\
\hline edup & $\%$ & 630 & 5.295 & 1.25 & 2.38 & 9.83 \\
\hline eip & $\%$ & 630 & 1.084 & 0.968 & 0.16 & 7.04 \\
\hline $\ln (\mathrm{road})$ & 10 thousand kilometers & 630 & 11.263 & 0.82 & 9.11 & 12.69 \\
\hline GEUH(popu) & 10 thousand persons & 630 & 7.841 & 0.792 & 6.21 & 9.05 \\
\hline
\end{tabular}

\section{Research results and discussion}

\section{Descriptive statistics}

The results of the descriptive statistics of indicators are shown in Table 2.

\section{Results and discussion}

The test results of the dynamic mechanism of green development are shown in Table 3.

(1) External dynamics. In Table 3, Models 1-4 are the test results of external dynamics. It is clear that the
Table 3 Test results of the dynamic mechanism of green development in China

\begin{tabular}{|c|c|c|c|c|c|c|c|}
\hline Variables & Model (1) & Model (2) & Model (3) & Model (4) & Model (5) & Model (6) & Model (7) \\
\hline \multirow[t]{2}{*}{$\ln \left(\operatorname{exter}_{1}\right)$} & $0.023 * *$ & $0.017 * *$ & & & & & \\
\hline & $(2.07)$ & $(2.23)$ & & & & & \\
\hline \multirow[t]{2}{*}{ exter $_{2}$} & & & $0.004 * *$ & $0.004 * *$ & & & \\
\hline & & & $(2.34)$ & $(2 . .49)$ & & & \\
\hline \multirow[t]{2}{*}{ inner } & & & & & -0.008 & -0.008 & -0.008 \\
\hline & & & & & $(-1.57)$ & $(-1.45)$ & $(-1.47)$ \\
\hline \multirow[t]{2}{*}{ fip } & -0.004 & -0.001 & -0.001 & & -0.001 & & -0.001 \\
\hline & $(-0.46)$ & $(-0.17)$ & $(-1.07)$ & & $(-0.56)$ & & $(-1.15)$ \\
\hline \multirow[t]{2}{*}{ urp } & & & $0.002 *$ & 0.00 & & & \\
\hline & & & $(1.81)$ & $(1.56)$ & & & \\
\hline \multirow[t]{2}{*}{ inp } & $-0.004 * *$ & $-0.005 * * *$ & & & $-0.005 * * *$ & & \\
\hline & $(-2.56)$ & $(-2.70)$ & & & $(-2.66)$ & & \\
\hline \multirow[t]{2}{*}{ edup } & $-0.019^{*}$ & -0.016 & -0.008 & -0.013 & $-0.019^{*}$ & -0.017 & -0.015 \\
\hline & $(-1.76)$ & $(-1.55)$ & $(-0.71)$ & $(-1.21)$ & $(-1.67)$ & $(-1.53)$ & $(-1.34)$ \\
\hline \multirow[t]{2}{*}{ eip } & $0.037 * *$ & $0.038 * *$ & & 0.025 & $0.039 * *$ & $0.031 *$ & $0.037 * *$ \\
\hline & (2.14) & (2.17) & & (1.48) & $(2.21)$ & $(1.83)$ & (2.09) \\
\hline \multirow[t]{2}{*}{$\ln ($ road $)$} & & & -0.001 & -0.019 & $0.040 *$ & 0.021 & 0.036 \\
\hline & & & $(-0.05)$ & $(-0.97)$ & $(1.80)$ & (1.14) & (1.66) \\
\hline \multirow[t]{2}{*}{$\ln ($ popu $)$} & -.044 & & -0.28 & -0.006 & -0.054 & -0.041 & -0.058 \\
\hline & $(-1.18)$ & & $(-0.75)$ & $(-0.17)$ & $(-1.22)$ & $(-0.99)$ & $(-1.33)$ \\
\hline \multirow[t]{2}{*}{ _cons } & $0.583 *$ & $0.026^{* *}$ & 0.347 & 0.334 & 0.474 & 0.311 & 0.345 \\
\hline & (1.97) & $(2.01)$ & $(1.28)$ & (1.24) & (1.46) & $(0.98)$ & (1.07) \\
\hline R-squared & 0.1577 & 0.1596 & 0.2634 & 0.2494 & 0.0031 & 0.058 & 0.0582 \\
\hline $\begin{array}{l}\text { Category of } \\
\text { models }\end{array}$ & $\begin{array}{r}\text { Random } \\
\text { effect }\end{array}$ & $\begin{array}{r}\text { Random } \\
\text { effect }\end{array}$ & $\begin{array}{r}\text { Random } \\
\text { effect }\end{array}$ & $\begin{array}{r}\text { Random } \\
\text { effect }\end{array}$ & $\begin{array}{r}\text { Random } \\
\text { effect }\end{array}$ & $\begin{array}{r}\text { Random } \\
\text { effect }\end{array}$ & $\begin{array}{r}\text { Random } \\
\text { effect }\end{array}$ \\
\hline
\end{tabular}

Note: ***,** and $*$ mean that the variables are significant at the levels of $1 \%, 5 \%$ and $10 \%$, respectively; the figure in the bracket of the fixed effect model is the $Z$-value, and the figure in the bracket of the random effect model is the $T$-value. 
public demands have passed the significance test, indicating that more public demands on green development can promote the green development, which also confirms the effectiveness of external dynamics. The results support the views of Liao and Shi (2018). They argued that public demands on the environment have contributed to stricter environmental regulation and increased investment in environmental governance by local governments and businesses. We believe that results can be explained in four aspects:

Firstly, sociology holds that the role of the public in the national governance system can be analyzed from the perspectives of democracy, politics and the economy. In terms of democracy, the public demands should be fully reflected in the process of government decision-making ((Shepherd and Bowler 1997); on the part of politics, conforming to the public interest is the key criterion to judge the soundness of governance (Shepherd and Bowler 1997); from the perspective of economy, the public are the demanders of surplus value of a country, which determines the mechanism of the performance of government contract (Williamson 1996). The public has natural authority on the importance of the country and government. Therefore, the public demands on green development and the political pressure accompanied will be transformed into impetus and traction of the government to improve the national governance, which essentially reflects the return of state power to the society and the democratization of the political process. It is conducive to improving the public's recognition of the government and its authority.

Secondly, the public's pursuit of happiness is also an important factor in promoting green development. It indicates theoretically and practically that while economic growth has achieved results, the happiness of Chinese people has not risen accordingly. Instead, the "Easterlin Paradox" has emerged (Easterlin 1995). "Easterlin Paradox" was emerged because, during social development, people paid too much attention to wealth, such as per capita income and consumption level instead of ignoring other factors (Yasar 2018). As the economy develops, if these non-economic factors are negatively related to wealth, these neglected variables will offset the positive effects of economic factors, resulting in the "Easterlin Paradox" (Jr Rosser 2017; Opfinger 2016). In China, in the early stage of reform and opening, the ecological environment had not received due attention. It has become a neglected variable, which will undoubtedly reduce public happiness (Li 2016; Yang et al. 2020). As a result, the public's yearning for a better life will trigger more demands on green development, increase political pressure and prompt the government to improve the supply capacity of green development continuously.
Thirdly, under the threat of the "Middle-income Trap", the public's new demand for transformation will also promote green development. The "Middle-income Trap" is that when a country or a region's per capita income reaches the medium level of the world, it is prone to insufficient economic growth momentum, stagnant or even retrogressive development, and a general decline in the real wealth of its citizens. Some countries fell into the "Middle-income Trap" because they had failed to change their development mode in a timely manner (Bulman et al. 2017), resulting in overconsuming energy, serious pollutions and development difficulties. At that time, the public would fully realize the importance of transformation and put forward urgent demands for transformation. In 2009, China's per capita GDP reached $\$ 3838$, facing the challenge of dropping into the "Middle-income Trap". To get out of the "development bottleneck", it was necessary to maintain a necessary pace of development, but the challenges of the environment could not be avoided. Since there was no mechanism for "automatically improving the environment as a country's income rises" (Baland et al. 2010), a development model at the expense of the environment was likely to plunge China into a vicious circle. Green development is essentially a transformation of development mode. Therefore, during this period, the public would encounter income decline, unemployment increase, social welfare declines and other expected factors, and then put forward the demand for transformation, which will form the external pressure for green development.

Fourthly, democratic discussion and public opinion on the environment have further increased the political influence on the demand for green development. Democratic discussion is essential for government officials' performance assessment. Although only a few people can participate in democratic appraisal, it also puts great pressure on government officials. In addition, because public opinion events and mass incidents have the function of a one-vote veto, the government pays more attention to the public demand on green development, especially the mass demand. In 2017, General Secretary Xi Jinping said: "Party committees, governments and leading cadres at all levels should insist on handling public complaints and proposals as an important task for understanding people's conditions, pooling their wisdom, safeguarding their interests and gathering popular sentiments, effectively address the reasonable demands of the public promptly by the law, pay attention to prevention at the source, and consolidate the grass-roots foundation." Since then, China has successively improved public complaints and proposals, and provided path guidance and institutional support for local governments to regulate and strengthen the management of public demands. These measures have increased the political influence of the public on green development. 
(2) Internal dynamics. Models 5-7 in Table 3 show that the political promotion willingness of local government officials is not significant with green development, which indicates that the political promotion willingness of local government officials has not been transformed into the willingness to promote green development. The internal driving force of green development is not effective. There are three main reasons:

First, in a sense, the assessment content of the central government directly determines the momentum of the local government to promote development. In the research period, the scale of GDP and the speed of economic development were key evaluation indicators that determined the political promotion of local government leaders. Especially in the context of economic downturn and pressure increase, scale and quantity were particularly important. In recent years, although the central government has included the resources and environment in the scope of assessment of local government officials, but most of them were deducting-mark indicators. The local government administrators have no higher willingness to save energy and reduce emissions once they accomplish the basic targets. Under the influence of the central government's "baton" of assessment, some industries which are of high consumption of energy and high pollution are welcomed by local governments because it helps officials to stand out in regional competitions due to more employment and economic contribution. This phenomenon could also be confirmed from the energy consumption in China: In 2005, China's economic aggregate accounted for $4.95 \%$ globally, while its energy consumption accounted for 14.64\%; in 2018, China's economic aggregate reached $15.67 \%$, but energy consumption also increased to about 25\% globally. From 2005 to 2018, China's energy consumption grew at an average annual rate of $5.3 \%$, much higher than the global average of $1.8 \%$. The assessment method valued scale and quantity caused space-time asymmetry between the benefits and cost of "political performance" and intensified the short-term behavior of local governments, further weakening the endogenous driving force of green development.

Second, the transition period of green development is long, and the effect has not been fully demonstrated. Green development is the second generation of sustainable development concept (Cao et al. 2019; Zou et al. 2019), which not only takes environmental protection as an important content but also takes the "green" and "ecological" of the process and results as the way and requirement in economic activities; it can reflect the transformation effect of the development mode. The transformation of economic development mode is a longterm process, especially the concentrated emission of pollutants caused by China's "squeeze" industrialization (Xiao et al. 2020), which increases the difficulty of green development transformation. Adjusting industrial structure and eliminating high-polluting industries are bound to affect employment and social stability. The increase of unemployed people will lead to the increase of social security and other expenditures, as well as the costs of personnel placement and the bad debts in financial institutions, which will extend the cycle of development mode transformation. In addition, the transformation of green development needs the corresponding development concept, system supply, cultural atmosphere and organizational guarantee. Compared with it, the tenure of local government officials is relatively short, which will also increase the lag of the green development effect.

Third, the imbalance of regional development in China has weakened the effect of green development. In 2018, the per capita GDP of 10 provinces in eastern China reached $\$ 13,000$, moving towards a high-income phase, while the per capita GDP in the western region was less than $\$ 7100$. What is worse, the western region also suffered multiple pressures from economic development, resource protection and environmental constraints. The imbalance of regional development led to different green development effects in different regions even if they had the same development willingness, weakening the test results.

\section{Robustness and endogenous test}

In Table 3, Models 1-2 and Models 3-4 respectively adopted the total number of public complaints and proposals received and the number of public complaints and proposals per 10,000 persons as independent variables, and both have passed the significance test, indicating that the impact of public demands on green development is stable. In this paper, the public demand index was changed to the number of environmental proposals of local NPC deputies and CPPCC members (pieces) as well as the Riming number of environmental proposals per 10,000 NPC deputies. Both still passed the significance test (due to limited space, it would not be listed but available for reference). In Models 5-7 of Table 3, after different control variables were controlled, the internal dynamics failed the significance test, which shows that the test results of the internal and external dynamics mechanism in this paper are stable and reliable.

In the endogenous test, firstly, the Davison-MacKinnon test was used to verify endogeneity. Its null hypothesis is that endogeneity had no obvious impact on the estimated results of OLS; that is, there was no endogeneity. However, there were issues of endogeneity in models 1-7, presented in Table 4.

In order to overcome the issues of endogeneity, we adopted the one-period lag and two-period lag of independent variable to retest models $1-7$ by two-step system GMM estimation; the results are shown in Table 5. Obviously, the external dynamics was significant, but the internal dynamics was not.

To ensure the reasonableness of instrumental variables, we used the Anderson LR statistic to test under-identification in 
Table 4 Test results of the endogeneity

\begin{tabular}{llllllll}
\hline Test & $\begin{array}{l}\text { Model } \\
(1)\end{array}$ & $\begin{array}{l}\text { Model } \\
(2)\end{array}$ & $\begin{array}{l}\text { Model } \\
(3)\end{array}$ & $\begin{array}{l}\text { Model } \\
(4)\end{array}$ & $\begin{array}{l}\text { Model } \\
(5)\end{array}$ & $\begin{array}{l}\text { Model } \\
(6)\end{array}$ & $\begin{array}{l}\text { Model } \\
(7)\end{array}$ \\
\hline Davidson-MacKinnon & $7.46^{* * *}$ & $7.78^{* * *}$ & $6.63 * * *$ & $7.03 * * *$ & $9.22^{* * *}$ & $9.87^{* * *}$ & $9.85^{* * *}$ \\
\hline
\end{tabular}

the instrumental variables. The null hypothesis of Anderson LR was that there was no correlation between instrumental variables and endogenous variables. Sargan statistic was used to test over-identification, and the null hypothesis was that instrumental variables are reasonable. There were no underidentification and over-identification from the test results.

\section{Further discussion}

We have proved that external pressure from the public is an effective way to promote green development. So, what will affect the public's demand for green development? To address these issues, we constructed a test model as follows:

$$
\begin{aligned}
& \ln \left(\text { exter }_{1}\right)=C+\beta_{1} y_{i, t}+\sum \beta_{\mathrm{i}} x_{i, t}+\delta \\
& \text { exter }_{2}=C+\beta_{1} y_{i, t}+\sum \beta_{i} x_{i, t}+\delta
\end{aligned}
$$

$y_{i, t}$ represents a series of indicators that affect the public demands on the environment, namely, per capita disposable income of urban residentspincome, education levelyedu, economic development level (per capita GDP) pcgdp, per capita consumption expenditurepcconsum. yedu was calculated using formula (18). The one-period lag and two-period lag of independent variable were used equally to test Formulas (21) and (22) by two-step system GMM estimation against endogeneity; the test results are shown in Table 6.

Table 6 shows that any index of income level, consumption level, economic development level and individual education years had positive impacts on public demands of green development. With the improvement of economic development level and residents' education level, the public had a deeper understanding of environmental issues, gradually increased the attention and heightened the enthusiasm for environmental protection, which will form more and high-level green appeals on green development. The positive correlation between

\begin{tabular}{|c|c|c|c|c|c|c|c|}
\hline Variables & Model (1) & Model (2) & Model (3) & Model (4) & Model (5) & Model (6) & Model (7) \\
\hline $\ln \left(\right.$ exter $\left._{1}\right)$ & $\begin{array}{l}0.073 * * * \\
(3.17)\end{array}$ & $\begin{array}{l}0.048^{* *} \\
(2.42)\end{array}$ & & & & & \\
\hline exter $_{2}$ & & & $\begin{array}{l}0.007 * * \\
(2.06)\end{array}$ & $\begin{array}{l}0.006^{*} \\
(1.83)\end{array}$ & & & \\
\hline inner & & & & & $\begin{array}{l}-0.004 \\
(-0.32)\end{array}$ & $\begin{array}{l}-0.003 \\
(-0.27)\end{array}$ & $\begin{array}{l}-0.003 \\
(-0.23)\end{array}$ \\
\hline fip & $\begin{array}{l}-0.002 \\
(-0.22)\end{array}$ & $\begin{array}{l}-0.001 \\
(-0.52)\end{array}$ & $\begin{array}{l}-0.001 \\
(-0.21)\end{array}$ & $\begin{array}{l}-0.001 \\
(-0.75)\end{array}$ & $\begin{array}{l}-0.002 \\
(-1.41)\end{array}$ & $\begin{array}{l}-0.001 \\
(-1.05)\end{array}$ & $\begin{array}{l}-0.002 \\
(-1.45)\end{array}$ \\
\hline urp & & & & & $\begin{array}{l}0.006^{* * *} \\
(2.41)\end{array}$ & & \\
\hline inp & $\begin{array}{l}-0.003 \\
(-1.31)\end{array}$ & $\begin{array}{l}-0.001 \\
(-0.44)\end{array}$ & $\begin{array}{l}-0.003 \\
(-1.26)\end{array}$ & $\begin{array}{l}-0.003 \\
(-1.46)\end{array}$ & $\begin{array}{l}-0.005 * * \\
(-2.12)\end{array}$ & $\begin{array}{l}-0.004 * \\
(-1.76)\end{array}$ & \\
\hline edup & $\begin{array}{l}-0.026^{*} \\
(-1.90)\end{array}$ & $\begin{array}{l}-0.011 \\
(-0.87)\end{array}$ & $\begin{array}{l}-0.014 \\
(-0.99)\end{array}$ & $\begin{array}{l}-0.016 \\
(-1.19)\end{array}$ & $\begin{array}{l}-0.020 \\
(-1.47)\end{array}$ & $\begin{array}{l}-0.013 \\
(-1.26)\end{array}$ & $\begin{array}{l}-0.008 \\
(-0.61)\end{array}$ \\
\hline eip & $\begin{array}{l}0.042 * * \\
(2.30)\end{array}$ & $\begin{array}{l}0.039 * * \\
(2.13)\end{array}$ & & $\begin{array}{l}0.041 * * \\
(2.28)\end{array}$ & $\begin{array}{l}0.042 * * \\
(2.35)\end{array}$ & $\begin{array}{l}0.044 * * \\
(2.47)\end{array}$ & $\begin{array}{l}0.042^{* *} \\
(2.34)\end{array}$ \\
\hline $\ln ($ road $)$ & & & $\begin{array}{l}0.081 * * \\
(2.55)\end{array}$ & $\begin{array}{l}0.086 \text { **** } \\
(2.71)\end{array}$ & $\begin{array}{l}0.065^{*} \\
(1.85)\end{array}$ & $\begin{array}{l}0.120 * * * \\
(4.37)\end{array}$ & $\begin{array}{l}0.113 * * * \\
(4.16)\end{array}$ \\
\hline $\ln ($ popu $)$ & $\begin{array}{l}-0.508 * * * \\
(-2.68)\end{array}$ & & $\begin{array}{l}-0.537 * * * \\
(-2.98)\end{array}$ & $\begin{array}{l}-0.556^{* * * *} \\
(-3.10)\end{array}$ & $\begin{array}{l}-0.625^{* * *} \\
(-3.3)\end{array}$ & $\begin{array}{l}-0.433 * * \\
(-2.50)\end{array}$ & $\begin{array}{l}-0327 * * \\
(-2.02)\end{array}$ \\
\hline $\mathrm{F}$ & $3.29 * * *$ & $4.10 * * *$ & $4.60 * * *$ & $4.75 * * *$ & $4.46^{* * *}$ & $4.24 * * *$ & $4.42 * * *$ \\
\hline Anderson LR & $208.07 * * *$ & $242.25^{* * *}$ & $206.91 * * *$ & $217.86^{* * *}$ & $75.41 * * *$ & $89.37 * * *$ & $97.5^{* * *}$ \\
\hline Sargan & 0.526 & 0.002 & 0.0001 & 0.0008 & 1.359 & 1.516 & 1.249 \\
\hline Instrumental variables & \multicolumn{2}{|l|}{$\begin{array}{l}\text { L1. } \ln \left(\text { exter }_{1}\right) \\
\text { L2. } \ln \left(\text { exter }_{1}\right)\end{array}$} & \multicolumn{2}{|c|}{ L1. exter 2 , L1. exter 2} & \multicolumn{2}{|c|}{ L1. inner, L2. inner } & \\
\hline
\end{tabular}

Table 5 Retest results of IV on GMM estimation 
Table 6 Test results of public demands on the environment

\begin{tabular}{|c|c|c|c|c|c|c|c|c|}
\hline Dependent variables & $\begin{array}{l}\ln (\text { exter1) } \\
\text { Model (1) }\end{array}$ & $\begin{array}{l}\text { exter2 } \\
\text { Model (2) }\end{array}$ & $\begin{array}{l}\ln (\text { exter1) } \\
\text { Model (3) }\end{array}$ & $\begin{array}{l}\text { exter2 } \\
\text { Model (4) }\end{array}$ & $\begin{array}{l}\ln (\text { exter1) } \\
\text { Model (5) }\end{array}$ & $\begin{array}{l}\text { exter2 } \\
\text { Model (6) }\end{array}$ & $\begin{array}{l}\ln (\text { exter1) } \\
\text { Model (7) }\end{array}$ & $\begin{array}{l}\text { exter2 } \\
\text { Model (8) }\end{array}$ \\
\hline pincome & $\begin{array}{l}0.369 * * * \\
(4.54)\end{array}$ & $\begin{array}{l}4.284 * * * \\
(7.66)\end{array}$ & & & & & & \\
\hline yedu & & & $\begin{array}{l}1.125 * * * \\
(6.4)\end{array}$ & $\begin{array}{l}7.38 * * * \\
(6.05)\end{array}$ & & & & \\
\hline pcgdp & & & & & $\begin{array}{l}0.768 * * * \\
(4.58)\end{array}$ & $\begin{array}{l}7.84 * * * \\
(6.81)\end{array}$ & & \\
\hline pconsum & & & & & & & $\begin{array}{l}0.519 * * * \\
(3.57)\end{array}$ & $\begin{array}{l}6.02 * * * \\
(6.00)\end{array}$ \\
\hline fip & $\begin{array}{l}0.003 \\
(1.03)\end{array}$ & $\begin{array}{l}-0.089 * * * \\
(-4.17)\end{array}$ & $\begin{array}{l}0.001 \\
(0.21)\end{array}$ & $\begin{array}{l}-0.095 * * * \\
(-4.34)\end{array}$ & $\begin{array}{l}-0.002 \\
(-0.48)\end{array}$ & $\begin{array}{l}-0.133 * * * \\
(-5.87)\end{array}$ & $\begin{array}{l}0.002 \\
(0.07)\end{array}$ & $\begin{array}{l}-0.121 * * * \\
(-5.35)\end{array}$ \\
\hline urp & $\begin{array}{l}0.038 * * * \\
(4.92)\end{array}$ & $\begin{array}{l}0.058 \\
(1.11)\end{array}$ & $\begin{array}{l}0.009 \\
(0.87)\end{array}$ & $\begin{array}{l}-0.031 \\
(-0.45)\end{array}$ & $\begin{array}{l}0.029 * * * \\
(3.32)\end{array}$ & $\begin{array}{l}-0.001 \\
(-0.01)\end{array}$ & $\begin{array}{l}0.035 * * * \\
(3.99)\end{array}$ & $\begin{array}{l}0.032 \\
(0.52)\end{array}$ \\
\hline inp & $\begin{array}{l}0.001 \\
(0.11)\end{array}$ & $\begin{array}{l}-0.023 \\
(-0.57)\end{array}$ & $\begin{array}{l}-0.004 \\
(-0.62)\end{array}$ & $\begin{array}{l}-0.103 * * \\
(-2.42)\end{array}$ & $\begin{array}{l}-0.008 \\
(-1.32)\end{array}$ & $\begin{array}{l}-0.124 * * * \\
(-3.08)\end{array}$ & $\begin{array}{l}-0.005 \\
(-0.77)\end{array}$ & $\begin{array}{l}-0.086 * * \\
(-2.07)\end{array}$ \\
\hline edup & $\begin{array}{l}0.069 * \\
(1.86)\end{array}$ & $\begin{array}{l}0.392 \\
(1.55)\end{array}$ & $\begin{array}{l}0.063 * \\
(1.67)\end{array}$ & $\begin{array}{l}0.237 \\
(0.70)\end{array}$ & $\begin{array}{l}0.070^{*} \\
(1.91)\end{array}$ & $\begin{array}{l}0.385 \\
(1.53)\end{array}$ & $\begin{array}{l}0.059 \\
(1.60)\end{array}$ & $\begin{array}{l}0.275 \\
(1.09)\end{array}$ \\
\hline eip & $\begin{array}{l}-0.024 \\
(-0.50)\end{array}$ & $\begin{array}{l}0.159 \\
(0.55)\end{array}$ & $\begin{array}{l}-0.032 \\
(-0.66)\end{array}$ & $\begin{array}{l}0.022 \\
(0.97)\end{array}$ & $\begin{array}{l}0.002 \\
(0.04)\end{array}$ & $\begin{array}{l}0.459 \\
(1.42)\end{array}$ & $\begin{array}{l}-0.003 \\
(-0.07)\end{array}$ & $\begin{array}{l}0.402 \\
(1.24)\end{array}$ \\
\hline $\ln ($ road $)$ & $\begin{array}{l}-0.164 \\
(-1.61)\end{array}$ & $\begin{array}{l}-0.074 \\
(-0.11)\end{array}$ & $\begin{array}{l}-0.328 * * * \\
(-2.99)\end{array}$ & $\begin{array}{l}-0.211 \\
(-0.28)\end{array}$ & $\begin{array}{l}-0.288^{* *} \\
(-2.52)\end{array}$ & $\begin{array}{l}-1.08 \\
(-1.37)\end{array}$ & $\begin{array}{l}-0.217^{*} \\
(-1.89)\end{array}$ & $\begin{array}{l}-0.676 \\
(-0.86)\end{array}$ \\
\hline $\ln (\mathrm{popu})$ & $\begin{array}{l}-0.486 \\
(-0.81)\end{array}$ & $\begin{array}{l}-10.47 * * \\
(-2.54)\end{array}$ & $\begin{array}{l}-0.818 \\
(-1.40)\end{array}$ & $\begin{array}{l}-4.97 \\
(-1.23)\end{array}$ & $\begin{array}{l}0.637 \\
(1.27)\end{array}$ & $\begin{array}{l}3.131 \\
(0.91)\end{array}$ & $\begin{array}{l}0.433 \\
(0.83)\end{array}$ & $\begin{array}{l}0.238 \\
(0.07)\end{array}$ \\
\hline $\mathrm{F}$ & $56.39 * * *$ & $45.14 * * *$ & $56.67 * * *$ & $40.17 * * *$ & $57.36 * * *$ & $44.4 * * *$ & $55.74 * * *$ & $42.38 * * *$ \\
\hline Anderson LR & $413.6 * * *$ & $405.4 * * *$ & $207.92 * * *$ & $265.1 * * *$ & $496.9 * * *$ & $452.3 * * *$ & $462.5 * * *$ & $422.8 * * *$ \\
\hline Sargan & 0.676 & 1.242 & 0.641 & 1.42 & 1.063 & 0.001 & 1.039 & 1.545 \\
\hline Instrumental variables & $\begin{array}{l}\text { L1. pincome, } \\
\text { L2. pincome }\end{array}$ & & $\begin{array}{l}\text { L1. pedu, } \\
\text { L1. pedu }\end{array}$ & & $\begin{array}{l}\text { L1. pcgdp, } \\
\text { L2. pcgdp }\end{array}$ & & $\begin{array}{l}\text { L1. pccon } \\
\text { L2. pccon }\end{array}$ & \\
\hline
\end{tabular}

income and consumption levels shows that after the problem of food and clothing has been solved, people from all walks of life continue to enrich their understanding of the connotation of improving the quality of life. The public not only needs material and spiritual wealth but also pursue yearning for a better life. Ecological environment and development mode, as important parts of a better life, have naturally attracted public attention.

Consistent with the above, Anderson LR and Sargan statistical were used to verify the under-identification and overidentification; it can be seen the instrumental variables were valid.

\section{Conclusion}

In this study, green development dynamics were divided into external and internal dynamics. It was found that (1) the public demands on green development are positively related to green development; the driving force of China's green development is external dynamics, which is the political pressure formed by public environmental demands. (2) The internal dynamics of
China's green development is ineffective, and the political promotion intention of local government officials has not been transformed into an endogenous driving force to green development. The reasons are that the incentive mechanism of the central government for green development is not coordinated, as well as the reality of the slow transformation of green development and unbalanced regional development in China. (3) The public income level, consumption level, education level and macroeconomic development level would affect the public demand for the environment. It shows that the public environmental demands are closely related to the level of economic and social development.

The findings in this paper have certain implications for driving green development and accelerating the transformation of development modes. First, the central government should establish an assessment and motivation system to encourage green development. The above results showed the local government willingness was not obvious. One of the important reasons, as discussed, is that the central government has paid more attention to the scale and speed of local development than the efficiency in the past two decades; it affects the performance evaluation mechanism on local officials. The 
local government officials were also more concerned about scale and speed of development due to "political tournament". Therefore, it is time for the central government to change the evaluation mechanism completely. In June 2013, General Secretary Xi Jinping stressed in a meeting of the Central Organizations of the Party that "We should never judge a cadre simply by the growth of gross domestic product (GDP)". Subsequently, the Organization Department of the Central Committee of the CPC issued the Notice on Improving the Performance Evaluation of Local Leading Bodies and Cadres of Local Party and Governments, requiring that regional GDP and growth rates should not be taken as the major indicators to evaluate the performance of local leading bodies and cadres of local Party and governments. Since 2015, GDP assessments have been gradually "downplayed" in all the regions across China. However, due to a series of events, such as the China-United States trade war and the novel coronavirus epidemic, the downward pressure on the economy has increased, and "Ensuring growth and maintaining stable employment" has become the top priority. This paper argues that there is nothing intrinsically wrong with GDP, especially for the western region where development is an arduous task. However, the efficiency and quality of development must be emphasized while GDP is increased. It is recommended that the central government formulate a differential assessment system according to the characteristics of different regions. In the eastern region or the regions with less pressure from ecological protection, the assessment mode that pays equal attention to developing quality and scale should be adopted; the quality-based assessment model of development should be adopted in the central region and parts of the western region; in the key ecological protection regions, such as Tibet, Xinjiang, Qinghai, Gansu, Ningxia and Inner Mongolia, the assessment mode of ecological quality should be promoted, to form different ecological comparative advantages.

Second, public demands should be taken seriously, and channels for expressing public demands be widened. The results show that the external dynamics of green development is effective, and it is of practical significance to pushing green development through public demands. First, it is necessary to broaden the channels of public demands. With the help of "Internet +" and other new technology means, multiple channels such as telephones, SMS, WeChat, Weibo, live broadcast and Tik Tok should be provided for the public to express demands so that more demands can be extensively collected. Second, the assessment mechanism for public demands should be established. Responding to public demands on the environment and addressing public complaints are included in the assessment content of governments at all levels so that the problems reported by the public can be solved quickly; a transparent supervisory mechanism will be established for resolving demands so that the public can keep abreast of the process of resolving demands promptly. Third, it is urgent to establish a first-inquiry system. When the public report demands or complaints, the receptionists often shirk their responsibilities, which affects the public's perception and enthusiasm for supervision. To implement the "first-inquiry system" thoroughly, the department (or person) that is the first to receive complaints must take the lead in resolving complaints to avoid the "attenuation" of external pressure.

Availability of data and materials Not applicable.

Authors contribution ZL: conceptualization; data curation; formal analysis; investigation; methodology; writing an original draft. YH: resources; software; validation; visualization. JC: investigation; writingreview and editing. YD: review and editing. XY: supervision; funding acquisition. All authors read and approved the final manuscript.

Funding The paper is supported by China's statistical science research key program (2020LZ18).

\section{Declarations}

Ethics approval and consent to participate Not applicable.

Consent for publication Not applicable.

Competing interests The authors declare no competing interests.

\section{References}

Awan U, Arnold MG, Golgeci I (2021) Enhancing green product and process innovation: towards an integrative framework of knowledge acquisition and environmental investment. Business Strategy and the Environment 30(2):1283-1295. https://doi.org/10.1002/bse. 2684

Backhouse RE, Medema SG (2012) Economists and the analysis of government failure: fallacies in the Chicago and Virginia interpretations of Cambridge welfare economics. Cambridge Journal of Economics 36(4):981-994. https://doi.org/10.1093/cje/ber047

Baland JM, Bardhan P, Das S, Mookherjee D, Sarkar R (2010) The environmental impact of poverty: evidence from firewood collection in rural Nepal. Economic Development and Cultural Change 59(1): 23-61. https://doi.org/10.1086/655455

Bulman D, Eden M, Nguyen H (2017) Transitioning from low-income growth to high-income growth: is there a middle-income trap? Journal of the Asia Pacific Economy 22(1):5-28. https://doi.org/ $10.2139 /$ ssrn.2955575

Cao W, Zhang Y, Qian P (2019) The effect of innovation-driven strategy on green economic development in China - an empirical study of smart cities. International Journal of Environmental Research and Public Health, 16(9), Article Number:1520. DOI: https://doi.org/10. 3390/ijerph16091520

Chambers RG (2002) Exact nonradial input, output, and productivity measurement. Economic Theory 20(4):751-765. https://doi.org/10. $1007 / \mathrm{s} 001990100231$

Chung YH, Fare R, Grosskopf S (1997) Productivity and undesirable outputs: a directional distance function approach. Journal of 
Environmental Management 51(3):229-240. https://doi.org/10. 1006/jema.1997.0146

Chen Y, Yeh AGO, Zhang Y (2017) Political tournament and regional cooperation in China: a game theory approach. Annals of Regional Science 58(3):597-622. https://doi.org/10.1007/s00168-017-0809-6

Cheng G, Zervopoulos PD (2014) Estimating the technical efficiency of health care systems: a cross-country comparison using the directional distance function. European Journal of Operational Research 238(3):899-910. https://doi.org/10.1016/j.ejor.2014.05.007

de Medeiros JF, Lago NC, Colling C, Ribeiro JLD, Marcon A (2018) Proposal of a novel reference system for the green product development process (GPDP). Journal of Cleaner Production 187:984 995. https://doi.org/10.1016/j.jclepro.2018.03.237

Easterlin RA (1995) Will raising the incomes of all increase the happiness of all. Journal of Economic Behavior \& Organization 27(1):35-47. https://doi.org/10.1016/j.jclepro.2019.03.035

Fabrizi A, Guarini G, Meliciani V (2018) Green patents, regulatory policies and research network policies. Research Policy 47(6):10181031. https://doi.org/10.1016/j.respol.2018.03.005

Feng C, Huang J, Wang M (2018) Analysis of green total-factor productivity in China's regional metal industry: a meta-frontier approach. Research Policy 58:219-229. https://doi.org/10.1016/j.resourpol. 2018.05.008

Fike R, Gwartney J (2015) Public choice, market failure, and government failure in principles textbooks. Journal of Economic Education 46(2):207-218. https://doi.org/10.1080/00220485.2014.1002962

Gao J, Xiao Z, Wei H, Zhou G (2018) Active or passive? Sustainable manufacturing in the direct-channel green supply chain: a perspective of two types of green product designs. Transportation Research Part D: Transport and Environment 65:332-354. https://doi.org/10. 1016/j.trd.2018.09.007

Grillitsch M, Hansen T (2019) Green industry development in different types of regions. European Planning Studies 27:2163-2183. https:// doi.org/10.1080/09654313.2019.1648385

Galinato GI, Chouinard HH (2018) Strategic interaction and institutional quality determinants of environmental regulations. Resource and Energy Economics 53:114-132. https://doi.org/10.1016/j. reseneeco.2018.04.001

Hailu A, Veeman TS (2020) Environmentally sensitive productivity analysis of the Canadian pulp and paper industry, 1959-1994: an input distance function approach. Journal of Environmental Economics and Management 40(3):251-274. https://doi.org/10.1006/jeem. 2000.1124

$\mathrm{Hu}$ Y (2012) Energy conservation assessment of fixed-asset investment projects: an attempt to improve energy efficiency in China. Energy Policy 43:327-334. https://doi.org/10.1016/j.enpol.2012.01.009

Janaiah A, Hossain M, Otsuka K (2006) Productivity impact of the modern varieties of rice in India. Developing Economies 44(2):190-207. https://doi.org/10.1111/j.1746-1049.2006.00013.x

Jr Rosser JB (2017) Introduction to Special Issue of Review of Behavioral Economics Honoring Richard A. Easterlin. Reviews of Behavioral Economics, 4(4SI):295-300. DOI: https://doi.org/10.1561/105. 00000077

Keech WR, Munger MC (2015) The anatomy of government failure. Public Choice 164:1-42. https://doi.org/10.1007/s11127-0150262-y

Klein T A (2019) Comments on. Marketing systems and market failure. Journal of Macromarketing, 39(1SI):106-107. DOI: https://doi.org/ $10.1177 / 0276146718820939$

Kosar KR, Winston C (2008) Government failure versus market failure: microeconomics policy research and government performance. Public Administration Review 68(1):193-194. https://doi.org/10. 1111/j.1540-6210.2007.00851.x

Li J (2016) Why economic growth did not translate into increased happiness: preliminary results of a multilevel modeling of happiness in
China. Social Indicators Research 128:241-263. https://doi.org/10. 1007/s11205-015-1028-0

Li Z, Li D, Yang W, Qi X (2020) The spatial-temporal evolution and spatial convergence of ecological total factor productivity in China. Energy \& Environment, 7, Article Number:0958305X20941141. DOI: https://doi.org/10.1177/0958305X20941141

Liao X, Shi XR (2018) Public appeal, environmental regulation and green investment: evidence from China. Energy Policy 119:554-562. https://doi.org/10.1016/j.enpol.2018.05.020

Liu GT, Wang B, Zhang N (2016) A coin has two sides: which one is driving China's green TFP growth? Economic Systems 40(3):481498. https://doi.org/10.1016/j.ecosys.2015.12.004

Liu H, Liu Y, Wang H, Yang J, Zhou X (2019) Research on the coordinated development of greenization and urbanization based on system dynamics and data envelopment analysis - a case study of Tianjin. Journal of Cleaner Production 214:195-208. https://doi. org/10.1016/j.jclepro.2018.12.046

MacDonald S, Eyre N (2018) An international review of markets for voluntary green electricity tariffs. Renewable and Sustainable Energy Reviews 91:180-192. https://doi.org/10.1016/j.rser.2018. 03.028

Mekala GD, Hatton MacDonald D (2018) Lost in transactions: analysing the institutional arrangements underpinning urban green infrastructure. Ecological Economics 147:399-409. https://doi.org/10.1016/j. ecolecon.2018.01.028

Mittal S, Dhar RL (2016) Effect of green transformational leadership on green creativity: a study of tourist hotels. Tourism Management 57: 118-127. https://doi.org/10.1016/j.tourman.2016.05.007

Nin-Pratt A, Yu BX, Fan SG (2010) Comparisons of agricultural productivity growth in China and India. Journal of Productivity Analysis 33(3):209-223. https://doi.org/10.1007/s11123-009-0156-4

Noble GW (2021) Green Japan: environmental technologies, innovation policy, and the pursuit of green growth. Social Science Japan Journal 24(1):209-212. https://doi.org/10.1093/ssjj/jyaa047

Onuoha IJ, Aliagha GU, Rahman MSA (2018) Modelling the effects of green building incentives and green building skills on supply factors affecting green commercial property investment. Renewable and Sustainable Energy Reviews 90:814-823. https://doi.org/10.1016/j. rser.2018.04.012

Opfinger M (2016) The Easterlin paradox worldwide. Applied Economics Letters 23(2):85-88. https://doi.org/10.1080/13504851.2015. 1051650

Sarmiento CV, El Hanandeh A (2018) Customers' perceptions and expectations of environmentally sustainable restaurant and the development of green index: the case of the Gold Coast, Australia. Sustainable Production and Consumption 15:16-24. https://doi. org/10.1016/j.spc.2018.04.001

Shepherd A, Bowler C (1997) Beyond the requirements: improving public participation in EIA. Environmental Planning and Management 40:725-738. https://doi.org/10.1080/09640569711877

Simão L, Lisboa A (2017) Green marketing and green brand - the Toyota case. Procedia Manufacturing 12:183-194. https://doi.org/10.1016/ j.promfg.2017.08.023

Singh A, Philip D, Ramkumar J, Das M (2018) A simulation based approach to realize green factory from unit green manufacturing processes. Journal of Cleaner Production 182:67-81. https://oi. org/10.1016/j.jclepro.2018.02.025

Tao F, Zhang H, Hu Y (2017) Growth of green total factor productivity and its determinants of cities in China: a spatial econometric approach. Emerging Markets Finance and Trade 53(9):2123-2140. https://doi.org/10.1080/1540496X.2016.1258359

Tone K, Tsutsui M (2010) An Epsilon-based measure of efficiency in DEA - a third pole of technical efficiency. European Journal of Operational Research 207:1554-1563. https://doi.org/10.1016/j. ejor.2010.07.014 
Wang X, Zou H, Zheng Y, Jiang Z (2019) How will different types of industry policies and their mixes affect the innovation performance of wind power enterprises? Based on dual perspectives of regional innovation environment and enterprise ownership. Journal of Environmental Management, 251, Article Number:109586. DOI: https://doi.org/10.1016/j.jenvman.2019.109586, 251, 109586

Williamson OE (1996) The mechanisms of governance. Oxford University Press, New York

Xiao Y, Ma D, Cheng Y, Wang L (2020) Effect of labor cost and industrial structure on the development mode transformation of China's industrial economy. Emerging Markets Finance and Trade 56(8): 1677-1690. https://doi.org/10.1080/1540496X.2019.1694887

Yang X, Geng L, Zhou K (2020) Environmental pollution, income growth, and subjective well-being: regional and individual evidence from China. Environmental Science and Pollution Research 27: 34211-34222. https://doi.org/10.1007/s11356-020-09678-0

Yasar R (2018) Subjective well-being and income: a compromise between Easterlin paradox and its critiques. Economics-The Open Access Open-Assessment E-Journal, 12, Article Number:201843. DOI: https://doi.org/10.5018/economics-ejournal.ja.2018-43, 12
Ye B, Lin L (2020) Environmental regulation and responses of local governments. China Economic Review, 60, Article Number: 101421. DOI: https://doi.org/10.1016/j.chieco.2020.101421, 60, 101421

Yi P, Dong Q, Li W (2019) Evaluation of city sustainability using the deviation maximization method. Sustainable Cities and Society, 50, Article Number:101529. DOI: https://doi.org/10.1016/j.scs.2019. 101529, 50, 101529

Zhu B, Zhang M, Zhou Y, Wang P., Sheng J., He K., Wei Y.M., Xie R. (2019) Exploring the effect of industrial structure adjustment on interprovincial green development efficiency in China: a novel integrated approach. Energy Policy, 134, Article Number:110946. DOI: https://doi.org/10.1016/j.enpol.2019.110946, 134, 110946

Zou X, Lei C, Gao K, Hu C (2019) Impact of environmental decentralization on regional green development. Journal of Environment \& Development 28:412-441. https://doi.org/10.1177/ 1070496519870276

Publisher's note Springer Nature remains neutral with regard to jurisdictional claims in published maps and institutional affiliations. 